\title{
The degree to which faculty members at Imam Abdul Rahman bin Faisal University possess educational and social values from the students' viewpoint and its relationship to some variables.
}

\author{
Saddam Rateb Darawsheh, Assistant Professor, Community College, Department of Administrative Sciences \\ ,Imam abdulrahman Bin Faisal University, P.O .Box : 1982 , Dammam 43212 ,Saudi Arabia \\ ‘srdarawsehe@iau.edu.sa
}

Ahmed Mahmoud Elkilany, Self-Development Department, Preparatory Year Deanship and Supporting Studies, Imam Abdulrahman Bin Faisal University, Dammam, KSA, amelkilany@iau.edu.sa

Anwar Saud Al-Sha'ar, Deanship of Preparatory Year and Supporting Studies, Department of Self Development, Imam abdulrahman Bin Faisal University, P.O .Box: 1982 , Dammam 43212 ,Saudi Arabia

Sabrin Abdelaty Labib Abdelaty, Lecturer of Fundamentals OF Education, Department of Educational Sciences, College of Early Childhood Education, Alexandria University, Arab Republic of Egypt.

Yumna Ahmed Atoum, Education and Psychology Department, College of Science and Humanities, Imam abdulrahman Bin Faisal University. Jubail,Saudi Arabia

Hana youssef Faltakh, Department of Basic Sciences, Deanship of Preparatory Year and Supporting Studies, Imam Abdulrahman Bin Faisal University, hyfaltakh@iau.edu.sa

Hussein Mohamad Atoom, College Of Education Sciencec, Department of higher Education. Jerash University ,Jerash, Jordan, h.atoum@jpu.edu.jo

Lubna Abdullah abass almahdi, Assistant Professor, Community College, Department of Administrative Sciences,Imam abdulrahman Bin Faisal University, P.O .Box : 1982 , Dammam 43212 ,Saudi Arabia

\begin{abstract}
The progressive rise in technological and socio-economic dynamics has given rise to certain social challenges which resulted from inadequate transference of values successive generations among several societies. This study aims to ascertain the degree to which faculty members of Imam Abdul-Rahman Bin Faisal University possess educational and social values. To achieve this objective, a structured questionnaire was designed to collect primary data from 360 students of the university. A simple random sampling technique was used to select respondents. The data obtained were analyzed statistically with the aid of Statistical Package for Social Science (SPSS) 20. The results shows that most $(142,40.6 \%)$ of the students (respondents) reported that faculty members possessed high degree of imparting students with information and knowledge. Majority of the respondents (37.1\%) reported a low degree of freedom of students within the lecture. Also, the faculty members generally possessed a medium degree of social values such as integrity (35.1\%), modesty (39.4\%), empathy (36.6\%); training of students on social responsibility (39.4\%), altruism and enhancement of students' citizenship values (40.0\%); dedication/teamwork/healthy dealings with others (37.7\%). Furthermore, the correlation between educational and social values is 0.993 indicating a positively strong relationship between educational and social values. The p-value was less than 0.05 indicating that there was no statistically significant correlation between the variables of educational and social values.
\end{abstract}

Keywords: Imam Abdulrahman Bin Faisal University, educational, social, values, students, degree Received: 04.12.2020 $\quad$ Accepted: 20.01.2021 $\quad$ Published: 03.02.2021

\section{INTRODUCTION}

The progressive rise in technological and socio-economic dynamics has given rise to certain social challenges which resulted from inadequate transference of values successive generations among several societies. Majority of the rising social problems among families, schools and the society in general are closely associated with values. Sounieh Haddad. (2018). Intolerance and social violence, for example, are problems that are associated with such values. Generally, it is believed that effective process of teaching values if the most efficacious way to reduce and avoid such challenges which mar the social peace in a society. Several 
other occurrences ravaging social and global order have been conspicuously noticed. It is a common knowledge that majority of the individuals who perpetrate such acts were not given proper and adequate value education. Educating people on values is the most vital content of social control systems. Abdul Basit Howeidi, (2016). Also, as an integral aspect of social veracity, value education is a practical solution for current or future challenges at the local as well as global level.

\section{Significance of the Study}

The significance of the present research stems from:

The significance of university education in the agenda of evolution and expansion in the contemporary societies in one regard, and the significance of cultural and civilized values of these societies in another regard, since values are regarded as the foundation of any educational improvement. It has become the responsibility of Universities to prepare educators in every level of education; thus it becomes importance to understand the role of the university in building values among students.

\section{Objective of this Study}

the aim of this study is to ascertain the degree to which faculty members of Imam Abdul-Rahman bin Faisal University possess educational and social values from the point of view of the students.

\section{Research Problem}

The progressive rise in technological and socio-economic dynamics has given rise to certain social challenges which resulted from inadequate transference of values successive generations among several societies. Majority of the rising social problems among families, schools and the society in general are closely associated with values

\section{Research Questions}

In other to accomplish the research objectives, the researcher tried to answer the following questions:

1. What are the educational and social values prominent among the students of Imam Abdulrahman Bin Faisal University?

2. To what extent does the students possesses these values?

3. Is there a correlation between educational and social values among the students of Imam Abdulrahman Bin Faisal University?

\section{Research limitations}

The findings of the current research are limited to the research sample. The limited time and inadequate resources did not allow the researcher the opportunity to sample a larger data size for the study, thus, the findings from the study may not be generalized.

\section{LITERATURE REVIEW}

\section{Research terms}

\section{Values}

Values are defined linguistically, as stated in the Collective Meaning Dictionary, as a plural of the word value, which is a thing with a quantity, or a price, so the value of a thing is its value, the value of the property is its price, and the value of a person is what he improves.

The set of principles and controls that the individual acquires and forms the frame of reference in all his actions and actions that are relatively stable, and judgment on them differs from one society to another (Al-Najjar, Yahya, Abu Ghali, Attaf, 2017)

Another definition of values came as desirable and desired behaviors that individuals perform and practice in an expression of the extent of their belonging to the society in which they live and achieve their satisfaction and happiness, and society appreciates and accepts them and encourages individuals to practice them. (Sugar, Naji Ragab, 2018) 
Also, it has been defined as a set of moral standards and measures among people, which they spend on among themselves and take it as a measure by which they evaluate their work and judge by it their material and moral behavior. (Al-Jallad, Majid Zaki, 2010)

And in a final definition, they are convictions that contain moral implications that express the individual's thoughts about good and bad, right and wrong, and each individual has his own value system that defines his value priorities (Hani Al-Tawil, 2001)

According to Soykan (2007), the term value mirrors the worth, significance, desirability and the esteem an entity acquires in return. Value as a sociological idea refers to common desires and similarities in a society. Inkeles,.(2016), defined social values as "moral beliefs and principles that are accepted by the majority so as to ensure the continuity of a society". Aydın, ( 2011) Apart from the above characteristics, values do not indicate what exists but rather what ought to exist in the society as moral standards Fichter, (2017),Viewed in this way, values are adopted as honest points of view and set standards for what the society expected. Really, when people derive gratifications in similar things and derive pleasure from the same things, they refer common content of value. "What sociologists call collective consciousness are called by philosophers objective soul are the domain of common values" (Ülken, 2011). It is evident that no sociological, biological and psychological value would exist without the society. Traditions, language, arts, morals, and religion which give rise to the accepted core of the society can emerge only in a society. Taking the world as a being, humans get to understand communal ideals, visions, customs, arts, religion and morals through developing into a character (produce) from a being (seed) (Türkdoğan, 2010). Doğan (2011) noted that "Ethos is what anthropologists and sociologists call when they mean a society's profile of values which comes from a Greek word meaning common behaviors". According to Ülgener (2009), "Values that inspire and are inspired by a society can function both as a measure as well as something that are measured. In essence, values should be regarded as positive entities since Abu-Sakour And tayseer, (2009) "honesty" is a value; "intricacy" refers to lacking it. Values guide people as abstract entities that ordain people with ideal thinking and behavioral aspects such as being hard-working all the time. Hence, values are belief-based narratives that shape our approach to stuff and events". They therefore identify what is bad and what is good and direct people as conceptual entities. Altubayti and Hussein. (2016) The world and knowledge is evaluated by humans with the things they esteem as values. "What's human being? What's life? What's universe and how did it come into being? What's the value and function of knowledge?" Such terms like "Homo Economic us", "humans are machines" and "humans are created by God" vary due to the views and value process which these perceptions emerge from (Coser, 2007). In the twenty first century, progression of values is particularly essential due to the nature of this dispensation typified by advancement in technology. Also, it is essential to measure out standards for teaching value in this globalizing world in an age where values senselessly move around.

\section{Importance of values}

Values are of great importance and values are considered an evolving phenomenon, so it was necessary to look at them through the emerging milieu and to judge them in a situational judgment in relation to the standards set by society at a certain time and refer them to the circumstances surrounding the society's culture (Majid Al-Zeyoud. ,2011, p. , 58)

\section{Hierarchy of Values}

Many values like being honest, producing and working are considered to be more essential than some the public life. Also, people satisfy their desires one at a time and in other of priority. Therefore, the hierarchical structure of values can be viewed as a pyramidal structure. Kanad,. (2018). In our cognitive society, values take a hierarchical pattern. What lies behind a person's achievement are not one or more values; rather, it is a group of values. In the cognitive world, tools values are found at the bottom of the hierarchical structure. On the tools values, there are higher values which as well form a kind of hierarchy within it. "At the top there are the ultimate values such as oneness in religion, democracy in society, monogamy in family, justice in social life all of which interact in a given society" Koenig, ((2019). Higher values are viewed as essential signals of every society's welfare and continuity. In order of importance of values, high values are essential in every field. Justice for instance is applicable to family, economy and politics. The order of importance of values, when viewed from this perspective, must work together to make the society better. 


\section{Classification of Values}

There are several ways in which values can be classified, for instance, range (national, global and societal values), substance (artistic, scientific, academic, fiscal, social, and political values) and course (barter modes) traditional and modern values.

\section{Social Values}

These are also called societal values, they are the predominant values in a society in a sense or perception, which all guide them towards attaining a better society. Social values organize and regulate the day to day life of individuals in a society. Koenig, (2019). Values like sedulity, honesty, modesty and helpfulness are some examples of social values. From a sociological point of view, really, ideal values are exceptional only to a single society. Therefore, at one point in time, values are unique to only one group (Doğan, 2011). "Personal values are just as important as social values. Individual values are answers to the questions like which values make me great or inspire me? Alex Law and Michael Weitz define individual values as inspirational powers" (Bacanl, 2011).

The subject of values is considered a fertile field for studies in many disciplines, as researchers hardly agree about its concept, which is determined from the source drawn from it, in addition to that there are researchers who present about their study, especially in sociological research, because they believe that it falls outside the framework of research Empiricism, and that it cannot be subject to objectivity, while some Islamic researchers and thinkers tend to link it to the Islamic religion, which is what is termed Islamic values whose only source is the Holy Qur'an and the noble Sunnah, and it is a religious phenomenon that is studied in sociological research like all other social phenomena. (Haddad، 2018).

\section{National values}

These are values that values that are required for maintain the existence and unity of a nation. For example, the unity of the country, the sacredness of the national flag and the love for the country are all national values. Such values are necessarily vital to be in the world as a nation, definitely (Doğan, 2011). The main function of the national values is to unite people within a country while differentiating them from the world. National value and social values do not oppose each other, rather, they are developed upon each other. From this perspective, there can be societal values against the constitutional process which is spelt out by national values.

\section{Global Values}

These are values common to all societies. In the same way traditional values vary from one society to another and transform from time to time, globalization comes with new aspects to contemporary societies which are in essence not different from traditional ones. The manner societies view morals and virtues, patronage and trust, neighborhood relationships, privacy and serenity, betrayal and fidelity, fear and respect, tolerance and love either decline or change under the impact of globalization. Global values that influence societal values include knowledge, productivity, culture of competition, total quality, Kanad,. (2018) human rights, democracy, the individual and free market economy; with the individual being the most essential value of the knowledge society (postmodern society). Unlike societal values, global values are not comparative; rather, they are universal throughout. This particular statement is dependent on the choices of the societies. For instance, one can choose to rest in the societal domain or stay within the global sphere. "The main problem is how a traditional society surrounded by traditional values can move beyond the limitations posed by the society itself" (Doğan, 2011). It is noteworthy that science and technology are also values.

\section{Function of Values}

According to Bacanll, (2011), "Values in social system always take part at the beginning of activities, inside and at the end of the process because they are the powers which begin in the world of consciousness and conscience. Human beings and societies exist together with their values. Physical wealth of a society is also based on the perception, belief and values that the society has. Those cultural codes are road maps in a way to determine the routes of an individual and the society. As a result, in almost every society people take values seriously, sacrifice their interest, struggle for them and even they die for them". In this regard, Fitcher listed the functions of values as follows: ( Heba Ahmed El-Deeb (2019)

1. Values are employed as resources in judging. 
2. They act as social control and moderation implements.

3. They offer unity.

4. They play a part as a guide to realize and adopt social roles.

5. They reveal the manners of thinking and acting perfectly.

6. They make people concentrate on important and useful traditional objects.

\section{Education}

The survival of a society is quite impossible without education. Mialaret (2001) stated that "Societies survive with education; maintain their existence, development and permanence by means of educational institutions both generally and fundamentally". Education is a system that targets psychological, social, (Bacanll, 2011) moral and biological advancement of human being, who is a part of the society (Sabri, 2012). From this perspective, education is an organizational structure that assists in the development of individuals' identity, get him ready for life through transference of data, values and skills necessary for them. Education performs three common functions in a society, which are:

i. Protection: education helps to transmit the culture and values of the society to the people who live in the society. This make People to have similar life style through the process of socializing so as to make coherence and collaboration easy (Barbu,2008.).

ii. Commutative: education helps to transform people in improved way; pleasant patterns of behavior are developed in people, while unpleasant behavioral patterns are changed as well.( Bacanll,2011).

iii. Formative: "It is the function that paves the way for cultural innovation and scientific development of a society, which means improvement of new ideas" (Inkeles,2016)..

Education also targets societal advancement through a plan that identifies objective functions of education. (Macionis, 2010). The society must not be complacent with the already acquired knowledge but they must strive to improve on it, and also for new world discoveries (Özden, 2008). The objective of educational organizations is not limited to teaching alone but to assist students to get all values required as a human.

\section{Values education}

There are several means of identifying humans; nevertheless, fundamentally, humans are beings that create and possess values. Humans are special beings that require living together and dealing with one another. ( Özden, 2008)The rationale of life is not limited to gratification of material needs and life's ambitions but as well to develop individuals as humans and in spirit. While Manly Hall states "a man without any ethic values is a wild animal released to the world", Theodore Roosevelt noted that "to educate a man in mind and not in morals is to educate a menace to society." The aim of values education is to build values and increase people that transform their values to behaviors. Values cannot be acquired through describing or telling. Rather, values should be directly experienced, incorporated and they should be provided along the feelings associated with them. (Simsek, 2012), Values are made into characters through experience. The prerequisite of the values education is to create an atmosphere for the student where he is able to put his freewill to use. The type of education which is given by oppression, conditioning and insisting results to realization of others demands instead of its own. Providing an individual with the consciousness and confidence of being a person is among the fundamental objectives of education. Individuals that are not provided with such consciousness and exposed to too much socialization are poor in creativity. (Thornbur , 2013). "In the excessive socialization, uploading knowledge predominates rather than knowledge generation. Lack of confidence and creativeness effects social development in a negative way" (Mialaret, 2011)). In such cases, it becomes the duty of the society to educate such persons on their values. Factors like teacher, student, school atmosphere or environment, family, environment society, etc. are significantly vital in the attainment of values. In order to guarantee that individual build a trait based on values is possible only through education. Thus, it is imperative to inscribe values on individuals' minds for the sake society's existence, maintenance and prospect. And this is attained via education (Koening, 2019). The British Education Philosopher A. Whitehead's advise to the educationists is crucial "do not attempt to teach everything to the child but teach him very well what you teach so that the child can learn the learning and thinking" (Whitehead, 1959). "The purpose of educational institutions is not only to provide knowledge but also get the learners to gain values that make human beings human. The primary goals of schools are to get learners to gain values that are stated explicitly or not stated in the school program, discipline the students according to the determined rules, make contributions to their moral values and affect their characters positively. Fathi Hassan Malkawi 
(2020) Values are dreams and ideals that a society wants to accomplish. The key institution in accomplishing the ideals of a society is education. Dynamic and creative factor of education is the ideal factor that is produces. Societies without ideals cannot be happy" (Kanad, 2018). The sole path to becoming a society of values and information and remain a nation is via education. Value education intends to paint individuals in a society to uniform color. People in a society separate themselves other societies and show expected behavior for one another by making identical inclinations. This means that individuals in a society demonstrate similar behavior and inclination (Bacanll, 2011). Any society that does not take their values into consideration and actively hand such values down through cannot continue to exist in process of time. Systems of education that cannot identify and be attentive to the motivator characteristic of values constantly remain below the aims. Furthermore, (Altubayti and Hussein. 2016), handing down unknown or artificial values to people would be the greatest tragedy for a society. Additionally, the modern global and social events which prompt people say that "Where is the humanity?" "Does a human being do that?" have presented value education case to the program. Individuals in a society anticipate that children will attain their persona national values but for or even prior to the general values. Societies want to retain its existence and it can achieve this through the transfer of their own values to successive generations. Undeniably, this situation does not intend to disregard the general values.The most pressing issues in value education are listed below: ( Fichter, 2017).

a) Determination of the specific values to be acquired is among the most important issues of values education. For instance, official authority (government) and social values (customs and traditions) are the end product of value education. Thus, the choice of the authority on which values to teach as well as the values of the society are the major challenges of values education.

b) Another important issue in value education is choosing the extent to which national, global and social values should be incorporated into program.

c) In addition, "deciding on the level of the learners, the way and quantity of teaching are also important in value education. For instance, the most crucial years in the formation of permanent values are the childhood years when children's minds are pure. It is very difficult to change the values that are gained in these years. In the same way, to impose values upon adolescents in their secondary and higher education can result in the opposite conclusions of the expectations" (Çengel, 2011).

d) Lastly, deciding the type of method or model that will be followed is another major issue in value education. Several variables including school, family, media and religion) influence the formation of the individual's moral and mental world. Except these social organizations create a harmonious blend, the values that are taught in schools will not be sufficient for the value education. From this perspective, it is important for this type of social organizations to work together for the aim within the structure of blended models. (Whitehead,. 2009).

\section{Previous Studies}

- Abu-Sakour And tayseer (2009). Evaluated the "Role of Palestinian universities in the development of political awareness among young university students in Palestinian", the researcher employed a descriptive method and selected a random sample from universities in Palestine. The universities covered include Bethlehem University, Al-Quds Open University, Hebron University and Al-Quds University the total sample selected was one thaousand, one hundred and fifty female and male students. The results revealed that Palestine universities played a moderate role in the development of political awareness among students. In addition, the study established that there was no significant difference between the "role of Palestine universities in the development of political awareness that can be attributed to the variables of gender and the academic level".

- Baqer and Amin (2011) indicated that there is a value change in the value system of Iraqi society of a negative nature, as a result of the processes of social, economic and cultural change, as it is necessary to contain this segment of university students and study everything related to it in order to direct it or address its problems, so the research sample was Present. The current research seeks to achieve the following objectives: Building a scale to reveal the prevailing values among students of Tikrit University. ,. Measuring the nature of the prevailing values among students of Tikrit University. Identify the significance of the differences in the prevailing values among the students of Tikrit University according to the variables (gender, specialization, time period before and during the occupation). 4. Measuring the prevailing values for each of the six scale areas. And identifying the differences in the prevailing values for each domain according to the gender variable. The current research was identified by the students of Tikrit University. The two researchers reviewed a number of theories that explain the emergence, growth and change of values, and 
then they adopted the Springer theory. In order to achieve the objectives of the research, a value scale was constructed that consisted of six fields (scientific values, economic values, social values, religious values, political values, and aesthetic values) which were determined by the two researchers in light of the previous literature and the theory adopted. Paragraphs were formulated for each field to be answered according to a triple scale. The scale paragraphs were analyzed in two ways (the two extremes and the relationship of the paragraph score to the total score of the scale), and the two researchers verified the validity of the scale and consistency, and the study reached a set of research results, most notably: The average of the sample members reached (215.040) for the nature of values, which is higher than the hypothetical average which equals (162). This means that university students have a good level of commitment to values. Then I presented a number of: Recommendations. - The proposals

- And indicated the Khawaldeh (2013). This study aimed at identifying the level of the role of a faculty member in Jordanian universities in developing the values of citizenship from the students' point of view, and identifying the differences in the level of the role according to the variables of the student's gender, the university, the college, and the level of study. To achieve the objective of the study, a questionnaire was prepared, which included (48) paragraphs, and its validity and reliability were verified. The sample of the study consisted of (928) male and female students, who study in Jordanian universities, and the study showed that the level of the faculty member's role in developing citizenship values was average in general and in all fields. The results also showed that there are statistically significant differences due to variables: the student's gender in favor of males, the university variable in favor of private universities, the faculties variable in favor of colleges, humanity, and the study level variable in favor of first-year students. In light of the results, the researcher recommended a set of recommendations, the most prominent of which is that the university administration should give the issue of citizenship values the most attention, and instruct the faculty members to focus on these values and strengthen them in students 'hearts, and include them in the academic curricula

- Al-tubayti and Hussein (2016) researched on "The University Role in Developing values of citizenship among students of Tabouk university", their findings established that the highest value of citizenship was national loyalty. This was followed by dedication to societal customs and creative duty to the society. Furthermore, the study revealed that there was no significant difference at the level of citizenship as a result of discipline or standard of students of Tabuk University. The study also revealed that there was no statistically positive correlation between the role of the university administration and citizenship norms among female and male students of Tabuk University

- And Abdul Basit Howeidi indicated. (2016). The educational system is considered one of the most basic areas of social upbringing, and a means by which society aims to consolidate societal values and based on that, it is considered a social tool for preserving community values, as well as reproducing and integrating them, and a field for individual and collective practice with a decisive value dimension in crystallizing ethical behaviors that feed into social life. Hence, this system must embody the values of society and contribute to its advancement and building the capacities of scrutiny, criticism, and responsible mental choice among young people, in order to reach positive moral attitudes, whether individual or collective. In this article, we will try to review the most important social aspects addressed by the educational system, which are mainly represented in social values, and moral and human values

- The study aimed at Al-Mihdar (2017). To monitor the daily religious and humanitarian behavior of female students at Umm Al-Qura University, and to assess the degree of their practice in reality through the self-testimony of the female students themselves, and the statement of the faith values indicated by the daily behaviors of the students, in addition to identifying the role of some variables (marital status, college, place of residence The economic situation (in the self-assessment averages of the students 'self-esteem of their daily religious and humanitarian interactions in the Meccan society. The researcher used a tool designed by (AlAni, 4002 A.D.) after being subjected to honesty and reliability procedures to ensure its validity and suitability for study. The colleges of Umm Al-Qura University at Al-Zahir Campus during the second semester of the year $1436 \mathrm{AH}-1437 \mathrm{AH}$, and their number reached 386. The most important results were the following: The university students acknowledged with their self-assessments that they walked or practiced in their religious and human interactions (132 paragraphs) of the study tool, which It consists of (200 items) with averages ranging between $(4,984-4,207)$ on the pentagonal gradient to a degree always, i.e. practicing it continuously and doubts For $66 \%$ of the entire tool, and there were statistically significant differences in favor of female students in the Faculties of Sharia and Da'wah and Fundamentals of Religion versus the Faculties of Education and Social Sciences 
- Simsek (2018) carried out a study on "The Opinions of University Students about the Values They Acquired from Their Primary and Secondary School Teachers", the researcher employed interview and quantitative methodology as tools to select a random sample of two hundred and seventeen students comprising one hundred and forty males and one hundred and thirty-one females. The result of the research revealed that generally, there was a moderate level of practicing educational values among students and follows this order: 'personal, esthetical, social, religious'.

\section{METHODOLOGY}

Follow the descriptive curriculum by describing and analyzing the phenomenon ,In order to ascertain the degree to which faculty members of Imam Abdul-Rahman bin Faisal University possess educational and social values from the students' point of view and the their relationship to some variables, a structured questionnaire was designed to collect primary data from 360 students of the university. The survey design included questions about socio-demographic characteristics, views on educational and social values.

\section{Sample Size}

360 students were randomly selected as the representative sample of the Imam Abdul-Rahman bin Faisal University.

\section{Study Population}

The study population consisted of all students of Imam Abdulrahman Bin Faisal University.

\section{Sample Technique}

A simple random sampling technique was used to select respondents.

\section{Data Analysis}

The data obtained were analyzed statistically with the aid of Statistical Package for Social Science (SPSS) 20.

\section{RESULT AND DISCUSSION}

Three hundred and sixty (360) questionnaires were administered; of which three hundred and fifty, 350 (97.2\%) of them were duly completed and returned while the remaining $10(2.8 \%)$ of the questionnaires were not. The results of the data collected were represented in the tables below alongside discussion on findings in this study.

Table 1: Social Demographic Characteristics of the Respondents

\begin{tabular}{|l|l|l|l|}
\hline Variables & Categories & Frequency & Percentage \\
\hline \multirow{2}{*}{$\begin{array}{l}\text { Location } \\
\text { Headquarters }\end{array}$} & Dammam & 250 & 71.4 \\
\cline { 2 - 4 } Section & Qatif & 100 & 28.6 \\
\cline { 2 - 4 } & Administrative and Financial Science & 232 & 66.3 \\
\hline \multirow{2}{*}{ Gender } & Mamputer & 118 & 33.7 \\
\cline { 2 - 4 } & Female & 60 & 17.1 \\
\hline \multirow{2}{*}{ Academic Year } & First Year & 290 & 82.9 \\
\cline { 2 - 4 } & Second Year & 170 & 48.6 \\
\hline Total & & 180 & 51.4 \\
\hline
\end{tabular}

Table 1 gives a brief demography of the respondents (students). Most (71.4\%) of the respondents were from Dammam Governorate while the remaining 28.6\% of them were from Qatif Governorate both of which are in the Eastern Province. $66.3 \%$ of the respondents were of the department of Administrative and financial science while $33.7 \%$ of them were of the department of Computer Science. $17.1 \%$ of the respondents were male while the remaining $82.9 \%$ were female. $48.6 \%$ of the students were in their first academic year, while $51.4 \%$ of them were in their second year. 


\section{The First Question}

What are the educational and social values prominent among the students of Imam Abdulrahman Bin Faisal University?

The items that a related to the first research question are represented in table 2 bellow.

Table 2: Classification of the Degree of Educational and Social Values

\begin{tabular}{|l|l|}
\hline Values & Description \\
\hline Educational & Freedom of students within the lecture is appreciated \\
\cline { 2 - 3 } & Instilling the spirit of initiative among students for volunteer work. \\
\cline { 2 - 2 } & Imparting students with information and knowledge \\
\cline { 2 - 2 } & Developing among students the value of negotiation \\
\cline { 2 - 2 } & Students are persuaded with evidence and proof \\
\cline { 2 - 2 } & Collaborate with students on assignments and projects \\
\cline { 2 - 2 } & Others \\
\hline Social values & Integrity \\
\cline { 2 - 2 } & Modesty \\
\cline { 2 - 2 } & Empathy/Kindness \\
\cline { 2 - 2 } & Trains students on social responsibility \\
\cline { 2 - 2 } & Salaam at the start of a debate \\
\cline { 2 - 2 } & Altruism/Enhance Students' citizenship values \\
\cline { 2 - 2 } & Dedication/Teamwork/healthy dealings with other \\
\cline { 2 - 2 } & Others \\
\hline
\end{tabular}

The educational and social values identified among the students of Imam Abdulrahman Bin Faisal University are presented in table 2 above.

\section{The Second Question}

To what extent does the students possesses these values?

Table 3: Degree of Educational and Social Values

\begin{tabular}{|c|c|c|c|c|c|c|c|}
\hline \multirow[t]{3}{*}{ Values } & \multirow[t]{3}{*}{ Variables } & \multicolumn{6}{|c|}{ Degree/Level } \\
\hline & & \multicolumn{2}{|c|}{ High } & \multicolumn{2}{|c|}{ Medium } & \multicolumn{2}{|l|}{ Low } \\
\hline & & Freq & Perc. & Freq & Perc. & Freq & Perc. \\
\hline \multirow[t]{7}{*}{$\begin{array}{l}\text { Educational } \\
\text { values }\end{array}$} & $\begin{array}{l}\text { Freedom of students within the } \\
\text { lecture is appreciated }\end{array}$ & 100 & 28.6 & 120 & 34.3 & 130 & 37.1 \\
\hline & $\begin{array}{l}\text { Instilling the spirit of initiative } \\
\text { among students for volunteer work. }\end{array}$ & 120 & 34.3 & 108 & 30.9 & 122 & 34.9 \\
\hline & $\begin{array}{lcc}\text { Imparting students } & \text { with } \\
\text { information and knowledge } & \\
\end{array}$ & 142 & 40.6 & 112 & 32.0 & 96 & 27.4 \\
\hline & $\begin{array}{l}\text { Developing among students the } \\
\text { value of negotiation }\end{array}$ & 101 & 28.9 & 127 & 36.3 & 122 & 34.9 \\
\hline & $\begin{array}{l}\text { Students are persuaded with } \\
\text { evidence and proof }\end{array}$ & 93 & 26.6 & 108 & 30.9 & 149 & 42.6 \\
\hline & $\begin{array}{l}\text { Collaborate with students on } \\
\text { assignments and projects }\end{array}$ & 96 & 27.4 & 128 & 36.6 & 126 & 36.0 \\
\hline & Others & 87 & 24.9 & 138 & 39.4 & 125 & 35.7 \\
\hline \multirow{3}{*}{$\begin{array}{l}\text { Social } \\
\text { Values }\end{array}$} & Integrity & 118 & 33.7 & 123 & 35.1 & 109 & 31.1 \\
\hline & Modesty & 102 & 29.1 & 138 & 39.4 & 110 & 31.4 \\
\hline & Empathy/Kindness & 110 & 31.4 & 128 & 36.6 & 112 & 32.0 \\
\hline
\end{tabular}




\begin{tabular}{|l|l|l|l|l|l|l|l|}
\hline & $\begin{array}{l}\text { Trains students on social } \\
\text { responsibility }\end{array}$ & 109 & 31.1 & 138 & 39.4 & 103 & 29.4 \\
\cline { 2 - 9 } Salaam at the start of a debate & 100 & 28.6 & 123 & 35.1 & 127 & 36.3 \\
\cline { 2 - 7 } Students' & $\begin{array}{l}\text { Altruism/Enhance } \\
\text { citizenship values work/healthy }\end{array}$ & 89 & 27.7 & 140 & 40.0 & 113 & 32.3 \\
& $\begin{array}{l}\text { Dedication/Team } \\
\text { dealings with other }\end{array}$ & 93 & 26.6 & 139 & 39.7 & 118 & 33.7 \\
\hline
\end{tabular}

Table 3 shows the degree to which faculty members of Imam Abdul-Rahman bin Faisal University possess educational and social values. From the table, educational values (value education) possessed by faculty members were represented and discussed below.

Most $(142,40.6 \%)$ of the students (respondents) reported that faculty members possessed high degree of imparting students with information and knowledge, $112(32.0 \%)$ of the respondents reported an average level of impacting students with information and knowledge while the remaining, 96 (27.4\%) of them reported a low level of impacting students with information and knowledge amongst faculty members. Majority of the respondents (37.1\%) reported a low degree of freedom of students within the lecture; $34.3 \%$ of them reported a moderation in the degree of freedom of students within the lecture; while the remaining $28.6 \%$ reported a high degree of freedom among students within the lecture.

$34.3 \%$ and $34.9 \%$ of the respondents respectively reported a high and low degree of instilling the spirit of initiative among students for volunteer work; whereas $30.9 \%$ of them reported within the faculty members, an average degree of instilling the spirit of initiative among students for volunteer work.

Also observed within the table 3 is an average level (36.3\%) of negotiation developed among students; this modest degree of educational values is also observed in the collaboration of faculty members with students on assignments and projects (36.6\%).

Also represented in the table 3 are social values which encompassed integrity, modesty, empathy and the likes. It was reported that the faculty members generally possessed a medium degree of social values as represented in tables as follows: integrity (35.1\%), modesty (39.4\%), empathy (36.6\%); training of students on social responsibility (39.4\%), Altruism and Enhancement of Students' citizenship values (40.0\%); dedication/teamwork/healthy dealings with others (37.7\%); other reported forms of social values (39.7\%).

\section{The Third Question}

Is there a correlation between educational and social values among the students of Imam Abdulrahman Bin Faisal University?

Table 4: Correlation between educational and social values

\begin{tabular}{|l|l|l|l|}
\hline \multicolumn{2}{|l|}{ Correlations } & Educational values & Social values \\
\hline \multirow{4}{*}{ Educational values } & Pearson Correlation & 1 & $.993^{* *}$ \\
\cline { 2 - 4 } & Sig. (2-tailed) & & .000 \\
\cline { 2 - 4 } & Sum of Squares and Cross-products & 535.097 & 508.684 \\
\cline { 2 - 4 } & Covariance & 1.533 & 1.458 \\
\cline { 2 - 4 } & $\mathrm{N}$ & 350 & 350 \\
\hline \multirow{5}{*}{ Social values } & Pearson Correlation & $.993^{* *}$ & 1 \\
\cline { 2 - 4 } & Sig. (2-tailed) & .000 & 490.132 \\
\cline { 2 - 4 } & Sum of Squares and Cross-products & 508.684 & 1.404 \\
\cline { 2 - 4 } & Covariance & 1.458 & 350 \\
\cline { 2 - 4 } & $\mathrm{N}$ & 350 & \\
\hline **. Correlation is significant at the 0.01 level (2-tailed). & \multicolumn{2}{|l}{} \\
\hline
\end{tabular}

From the table 4 above, the correlation between educational and social values is 0.993 indicating a positively strong correlation between correlation between educational and social values from the point of view of the students. Thus, an increase in the educational values will result to an increase in social values. The 
p-value is less than 0.05 indicating that there is no statistically significant correlation between the variables of educational and social values.

\section{DISCUSSION}

The findings from the study as presented above grossly agree with the study of Simsek (2012), who reported that "the level of practicing educational values by students was generally moderate, and the dimensions appeared as follows: (personal, esthetical, social, and religious)". The study also shows similarity in result with the findings of Al-Thubaity and Hussein (2016) who reported high levels of social values among students in their study on "The University Role in Developing values of citizenship among students of Tabouk university". Lastly the result concurred with Al-tubaity and Hussein (2016) who in their study reported that "there was a statistic positive link between the role done by the university administration and citizenship norms among young males and females at Tabuk University".

\section{CONCLUSION AND RECOMMENDATIONS}

This study presents the degree to which faculty members at Imam Abdulrahman Bin Faisal University possess educational and social values. The findings clearly show that faculty members possessed high degree of imparting students with information and knowledge. The study also reveals that there is a low degree of freedom of students within the lecture. Furthermore, the study shows that the faculty members generally possessed a moderate degree of social values like integrity, modesty, empathy, social responsibility, Altruism and citizenship values, etc. The findings also show that value education is positively correlated to social values. Thus, an increase in the educational values will result to an increase in social values.

This study therefore recommends that there should be an improvement on the value education of the students of Imam Abdulrahman Bin Faisal University. Also, it is recommended that there should be a more flexible atmosphere for students during lectures as this will speed up their learning ability and thus improve their social values (Nickolov, 1991).

\section{Recommendations for further Studies}

Since this study was limited to Imam Abdulrahman Bin Faisal University, future researchers should carry out studies on other universities in Saudi Arabia. Also, this study only focused on interpersonal relationships among the students of the university under study, hence future researchers should carry out studies to ascertain social values of students in relation to the outside world.

\section{REFERENCES}

Abdul Basit Howeidi, (2016). The educational system and societal values, Journal of Research and Studies, Journal of $21 \mathrm{Al}$-Shaheed Hama Lakhdar El-Wadi University: Algeria

Abu-Sakour And tayseer, (2009). Role of Palestinian universities in the development of political awareness among young university students in Palestinian, Hebron University Journal for Research, Vol. 4, No. 1, pl 223-252.

Al-Najjar, Yahya, Abu Ghaly, and Attaf (2017). The role of higher education in promoting tolerance values from the viewpoint of students and faculty members at Al-Aqsa University as an example, Al-Aqsa University Journal (Human Sciences Series) Volume 21, P1 Gaza: Palestine

Altubayti and Hussein. (2016), "The University Role in Developing values of citizenship among Tabouk university", Taybeh Magazine for educational Science, Vol. 11 No. 3, 2006, pl 349365.

Aydın, M. (2011). Values, functions and morals. Eğitime Bakıș, 19, 39-45.

Bacanlı, H. (2011). Value is valuable. Eğitime Bakış, 19, 18-21.

Baqer, Moein and Amin, Amina. (2011). The prevailing values among university students in light of some variables, the Educational and Psychological Research Authority, P. 28, University of Baghdad Educational and Psychological Research Center, Iraq.

Barbu, Z. (2008). Society, culture and personality. Oxford: Basil Blackwell.

Çengel, Y. (2011). Human values for a safety future. Eğitime Bakış, 19, 13-17.

Coser, L. (2007). Ideas in historical and social context: Masters of sociological thought. USA: Harcourt Brace Jovannovich, Inc. 
Doğan, İ. (2011). Sociology of education. Ankara: Nobel Yayınları.

Ergil, D. (2009). Society and human. Ankara: Turhan Kitabevi.

Fathi Hassan Malkawi (2020) The System of Intentional Values 5.1.4.4, Edition 1, Volume 25, Issue 99, International Institute for Islamic Thought - Jordan Office: Jordan

Fichter, J. (2017). What is sociology? (Translated by Çelebi, N.). Ankara: Attila Bookstore.

Heba Ahmed El-Deeb (2019). New Media and Social Values: An Analytical View, Al-Arabi Journal for Media Studies, Volume 3, October: Egypt.

Inkeles, A.(2016). What is Sociology? USA Englewood Cliffs: Prentice-Hall,

Kanad, H. F. (2018). National idealism and national education, (Milliyet ideali ve topyekün milli terbiye). Ankara: Çankaya Matbaası.

Khawaldeh, Tayseer. (2013). The role of a faculty member in Jordanian universities in developing citizenship values from the students' point of view, Dirasat Journal, Educational Sciences, Volume 40, Appendix 3, The University of Jordan: Jordan

Koenig, S. (2019). Sociology, (Translated by S. Sucu \& O. Aykaç), İstanbul: Ütopya Kitapevi.

Long, Hani. (2001). Assessment and accountability as an introduction to educational systems management, the Lebanese Association for Educational Sciences conference, Educational Administration in the Arab Countries, Lebanon.

Macionis, J. (2010). Sociology. New Jersey: Prentice-Hall International.

Majid Al-Zyoud. (2011). Youth and Values in a Changing World, Al Shorouk Publishing and Distribution, Amman: Jordan.

Majid Zaki Al-Jallad. (2010). Learning and teaching values, Dar Al Masirah, 3rd floor, Amman: Jordan.

Mialaret, G. (2011). Les sciences de i'education (Translated by: H. Izgar \& M. Günsel). Ankara: Nobel.

Naji Rajab Sugar. (2018). The degree of Palestinian university youth's evaluation of the values of social cohesion and ways to enhance them, an applied study on Al-Aqsa University students, Al-Aqsa University Journal (Human Sciences Series) Gaza: Palestine

Nickolov, L.(2009). Everyday values vs. over socialization. International Sociology, 6, 375-379.

Özden, Y. (2008). Transformation of education, (Eğitimde dönüşüm). Ankara: Pegem Publications.

Sabri, F. Ü. (2012). Mental and ethic dimension of economic dissolution (İktisadi çözülmenin ahlak ve zihniyet dünyası). İstanbul: Der Yayınları.

Simsek, C. (2018) The Opinions of University Students about the Values They Acquired from Their Primary and Secondary School Teachers, International Journal of Educational Research and Technology, 3 (2), 30-37.

Sounieh Haddad. (2018). Social Values between Islamic Thought and Arab Thought, Journal of Social Sciences, Volume 14, and Humanity, Al-Arabi University, Tebessa, Tebessa, Algeria

Soykan, Ö. N. (2007). Is it possible a general valuable human moral? (Genel geçer bir ahlak olanaklı mıdır?). In K. Recep (Eds), Değerler ve E ğitim (pp 48-59). İstanbul: Dem Yayınları.

Thornburg H. D. (2013). Introduction to educational psychology. New York: West Publishing Company.

Türkdoğan, O. (2010). Matter of national culture in the Turkish sociology. (Türk sosyolojisinde milli kültür meselesi), Türk Dünyası Araştırmaları Dergisi, 18, 149-155.

Ülken, H. Z.( 2011). Knowledge and value (Bilgi ve değer). İstanbul: Ülken Yayınları.

Whitehead, A. (2009). The aims of education. New York: Macmillan.

Zaida, Princess Abdel Salam. (2020). Moral Values, Journal of the College of Education, Volume 20, P2, College of Education, Kafr El Sheikh University, Egypt. 